\title{
Pengaruh Aplikasi Arang Sekam dan Pupuk Organik Cair terhadap Pertumbuhan Tanaman Pakcoy (Brasicca rapa L.)
}

\section{The Effect of Husk Charcoal and Liquid Organic Fertilizer Application on the Growth of Pakcoy (Brasicca rapa L.) Plants}

\author{
Mujiono $^{1}$, Rosi Widarawati ${ }^{2}$, Budi Supono $^{3}$ \\ ${ }^{1,2,3}$ Balai Penelitian Tanaman Aneka Kacang dan Umbi
}

\begin{tabular}{l} 
ARTICLE INFO \\
\hline Article history: \\
DOI: \\
10.30595/pspfs.v2i.185 \\
Submitted: \\
July 29, 2021 \\
Accepted: \\
Sept 10, 2021 \\
Published: \\
Nov 10, 2021 \\
\hline
\end{tabular}

Keywords:

Pakcoy, Husk Charcoal, Liquid Organic Fertilizer

\begin{abstract}
This research aims to determine: 1) the effect of the comparison of the use of husk charcoal growing media with soil on the growth of pakcoy plants, 2) the effect of the application of liquid organic fertilizer (SO-Kontan Fert) on the growth of pakcoy plants, 3) the effect of a combination of rice husk planting media with soil and POC (SO-Kontan Fert) application to the growth of pakcoy plants. This research was conducted from January to March 2020 at the screen house of Melung Village, Baturraden District, Banyumas Regency, Central Java and the Agronomy and Horticulture Laboratory of the Faculty of Agriculture, Jenderal Soedirman University, with Andisol soil types. The experimental design used was a completely randomized block design (RAKL) with a 2-factor factorial design. The first factor is husk charcoal (M), namely, M0 = without husk charcoal, M1 = soil + husk charcoal (1: 1), M2 = soil (2: 1), soil + husk charcoal (3: 1). The second factor is the concentration of POC SO-Kontan Fert (P), namely, P0 = $0 \mathrm{ml}$ POC SO-Kontan Fert $/ \mathrm{Lt}$ water, P1 $=5 \mathrm{ml}$ POC SOKontan Fert / Lt water, P2 = $10 \mathrm{ml}$ POC SO-Kontan Fert / Lt water, P3 = $15 \mathrm{ml}$ POC SO-Kontan Fert / Lt water. Results of the research showed that giving husk charcoal to pakcoy plant media at a ratio of 3: 1 was able to increase plant height by $47.19 \mathrm{~cm}$ and leaf length by $26.13 \mathrm{~cm}$,. A ratio of 2: 1 can increase leaf greenness by 2.8 units. The application of liquid organic fertilizer (SO-Kontan Fert) with a concentration of $5 \mathrm{ml} / 1$ was able to increase the number of leaves by 6.59 .
\end{abstract}

This work is licensed under a Creative Commons Attribution 4.0 International License.

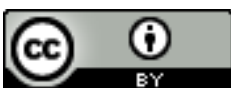

Corresponding Author:

Rosi Widarawati

Program Studi Agroteknologi Fakultas Pertanian

Universitas Jenderal Soedirman

Email: rosi.widarawati@unsoed.ac.id

\section{PENDAHULUAN}

Kebutuhan hasil pertanian semakin meningkat seiring jumlah penduduk yang semakin meningkat. Kemajuan teknologi semakin meningkat, menyebabkan industri seperti pabrik-pabrik semakin berkembang, sehingga menggeser banyak lahan pertanian terutama di daerah perkotaan yang mengakibatkan lahan pertanian semakin terbatas. Penyerapan nutrisi tanaman dipengaruhi oleh media tanam. Media tanam merupakan tempat akar tanaman menyerap unsur-unsur hara yang dibutuhkan oleh tanaman. Budidaya sayuran merupakan salah satu aspek penting dalam hortikultura. Sayuran memiliki kandungan nutrisi meliputi vitamin, serat dan mineral tinggi. Kandungan gizi dalam sayuran memberikan kontribusi bagi kesehatan manusia. Pakchoy (Brassica rapa 
L.) merupakan salah satu komoditas sayuran daun yang memiliki nilai ekonomis tinggi. Saat ini budidaya pakchoy berkembang pesat di daerah tropis karena pakchoy toleran terhadap suhu panas dan dapat berproduksi dengan baik di daerah yang bersuhu $27^{\circ}-32^{\circ} \mathrm{C}$. Pakchoy dapat dipanen dalam waktu singkat yaitu saat berumur 30-45 hari setelah tanam. Selain memiliki nilai ekonomis, pakchoy juga kaya vitamin, mineral dan protein, serta memiliki rasa yang tidak pahit dengan daun dan tangkai yang bertekstur lembut setelah dimasak (Rukmana, 1994). Produksi sawi pakcoy di daerah Jawa Tengah pada tahun 2018 mencapai 887,401 ton, dan pada tahun 2019 meningkat menjadi 983,246 (BPS, 2020). Hal tersebut menunjukkan bahwa produksi sayuran pakcoy mengalami penurunan pada tahun tersebut, sementara jumlah penduduk meningkat tak seiring dengan produksi yang dihasilkan. Oleh karena itu, produksi pakcoy perlu ditingkatkan untuk memenuhi kebutuhan tersebut.

Kesuburan tanah menjadi salah satu faktor penentu produktivitas tanaman. Peningkatkan produktifitas pakchoy dicapai melalui beragam cara pemupukan. Pupuk sebagai komponen untuk menambah nutrisi bagi tanaman, meliputi unsur hara makro maupun mikro. Tanaman sayuran daun membutuhkan asupan unsur nitrogen, fosfor, dan kalium dalam jumlah yang besar untuk proses pembentukan biomassa. Namun, dalam upaya pemenuhan unsur hara, budidaya tanaman sayuran, khususnya pakchoy masih menggantungkan pemberian pupuk kimia atau anorganik dengan dosis yang tinggi (Rosyida, 2017).

Media tanam merupakan komponen utama untuk bercocok tanam secara organik sehingga perlu disesuaikan dengan kebutuhan tanaman. Salah satu syarat media tanam yaitu mempunyai sifat fisik, kimia, dan biologi yang dibutuhkan tanaman. Upaya untuk meningkatkan kesuburan media tanam organik yaitu dengan cara menggunakan pembenah tanah seperti arang sekam yang bisa membantu proses perombakan bahan organik dan bisa memacu pertumbuhan tanaman, pemberian arang sekam mampu menghasilkan nilai tinggi pada variabel produksi tanaman baik bobot tanaman segar maupun bobot tanaman kering dengan perbandingan $3: 2$ bahan organik dan arang sekam (Suciati, 2018).

Pemberian pupuk organik cair harus memperhatikan konsentrasi diaplikasikan terhadap tanaman. Pemberian pupuk organik cair melalui daun memberikan pertumbuhan dan hasil tanaman lebih baik dari pada pemberian melalui tanah. Semakin tinggi konsentrasi pupuk diberikan maka kandungan unsur hara diterima oleh tanaman akan semakin banyak, begitu pula dengan semakin seringnya frekuensi aplikasi pemupukan dilakukan pada tanaman, maka kandungan unsur hara juga semakin tinggi. Perlu diperhitungkan dalam pemberian pupuk dengan konsentrasi berlebihan, karena akan mengakibatkan timbulnya gejala kelayuan pada tanaman. Pemberian konsentrasi dan frekuensi pemupukan harus disesuaikan dengan kebutuhan nutrisi tanaman (Wijaya, 2010).

Sekam bakar adalah media tanam yang porous dan steril dari sekam padi yang hanya dapat dipakai untuk satu musim tanam dengan cara membakar kulit padi kering di atas tungku pembakaran, dan sebelum bara sekam menjadi abu disiram dengan air bersih. Hasil yang diperoleh berupa arang sekam (sekam bakar). Arang sekam adalah sekam padi yang telah dibakar dengan pembakaran tidak sempurna. Cara pembuatannya dapat dilakukan dengan menyangrai atau membakar. Keunggulan sekam bakar adalah dapat memperbaiki sifat fisik dan kimia tanah, serta melindungi tanaman. Sekam padi memiliki aerasi dan drainasi yang baik, tetapi masih mengandung organisme-organisme pathogen atau organisme yang dapat menghambat pertumbuhan tanaman (Gustia, 2013).

Penelitiaan ini bertujuan untuk mengetahui: 1) pengaruh perbandingan penggunaan media tanam arang sekam dengan tanah terhadap pertumbuhan tanaman pakcoy, 2) pengaruh aplikasi pupuk organic cair (SOKontan Fert) terhadap pertumbuhan tanaman pakcoy, 3) pengaruh kombinasi media tanam arang sekam dengan tanah dan aplikasi POC (SO-Kontan Fert) terhadap pertumbuhan tanaman pakcoy.

\section{METODE PENELITIAN}

Penelitian ini dilaksanakan di Screen house Desa Melung, Kecamatan Baturraden, Kabupaten Banyumas dan Laboratorium Agronomi dan Hortikultura Fakultas Pertanian Universitas Jenderal Soedirman pada Januari 2020 sampai dengan Maret 2020.

\section{Bahan}

Bahan yang digunakan pada saat pelaksanaan penelitian yaitu tanah Andisol, benih pakcoy varietas Nauli F1, pupuk kandang sapi, arang sekam POC SO-Kontan Fert, air, dan polibag ukuran 30 x $40 \mathrm{~cm}$

\section{Alat}

Alat yang digunakan meliputi: beaker glass, polibag, $\mathrm{pH}$ meter, thermoygrometer, ember plastik, semprotan, pipet, timbangan, pengaduk kaca, penggaris panjang, corong, label, alat tulis dan kamera.

Penelitian ini dilakukan dengan menggunakan Rancangan Acak Kelompok Lengkap (RAKL) pola faktorial dengan 2 faktor dan 3 ulangan. Adapun perlakuan yang digunakan adalah :

Faktor I: Media arang sekam, terdiri dari 4 taraf, M0 = Tanah, tanpa arang sekam, M1 = Tanah + arang sekam (1:1), M2 = Tanah + arang sekam (2:1), M3 = Tanah + arang sekam (3:1). Faktor II: Konsentrasi POC SO-Kontan Fert, terdiri dari 4 taraf, P0 $=0 \mathrm{ml} \mathrm{POC} \mathrm{SO-Kontan} \mathrm{Fert/Lt} \mathrm{air,} \mathrm{P1} \mathrm{=} 5 \mathrm{ml}$ POC SO-Kontan Fert/Lt air, P2= $10 \mathrm{ml}$ POC SO-Kontan Fert/Lt air, P3= $15 \mathrm{ml}$ POC SO-Kontan Fert/Lt air. 
Variabel pengamatan dan pengukuran yang diamati dalam penelitian ini adalah: Tinggi tanaman $(\mathrm{cm})$, jumlah daun (helai), klorofil daun (unit), panjang daun $(\mathrm{cm})$, panjang akar $(\mathrm{cm})$, suhu $\left({ }^{0} \mathrm{C}\right)$, kelembaban $(\%), \mathrm{pH}$ tanah.

Data hasil pengamatan yang diperoleh pada variabel pengamatan dianalisis menggunakan analisis ragam uji $\mathrm{F}$ pada taraf $5 \%$ untuk mengetahui adanya pengaruh nyata pada setiap perlakuan. Apabila terjadi pengaruh nyata pada setiap perlakuan maka dilanjutkan dengan uji Duncan's Multiple Range Test (DMRT) pada taraf 5\% untuk mengetahui tingkat perbedaan antar perlakuan. Hasil perlakuan yang dibandingkan dengan kontrol menghasilkan satuan persen (\%), dapat ditentukan dengan rumus sebagai berikut :

$\%$ perlakuan $=\frac{\text { perlakuan }- \text { kontrol }}{\text { kontrol }} \times 100 \%$

\section{HASIL DAN PEMBAHASAN}

Hasil analisis ragam (Uji F) karakter pertumbuhan tanaman pakcoy pada perlakuan arang sekam yang dicampurkan dengan tanah dan penyemprotan pupuk organik cair (SO-Kontan Fert) di green house disajikan pada tabel 1, rerata data pengamatan variabel pertumbuhan disajikan pada Tabel 2.

Tabel 1. Hasil analisis ragam variabel pertumbuhan tanaman pakcoy (Brasicca rapa L.) pada perlakuan arang sekam dengan tanah dan penyemprotan pupuk organik cair (SO-Kontan Fert.

\begin{tabular}{|c|c|c|c|c|}
\hline \multirow{2}{*}{ No } & \multirow{2}{*}{ Variabel Pengamatan } & \multicolumn{3}{|c|}{ Perlakuan } \\
\hline & & $\mathrm{M}$ & $\mathrm{P}$ & $\mathrm{M} \times \mathrm{P}$ \\
\hline 1. & Tinggi Tanaman $(\mathrm{cm} / \mathrm{tan})$ & sn & tn & tn \\
\hline 2. & Panjang Daun (cm/tan) & sn & tn & tn \\
\hline 3. & Jumlah Daun (helai/tan) & tn & $\mathbf{n}$ & tn \\
\hline 4. & Kehijauan Daun (unit) & $\mathbf{n}$ & tn & tn \\
\hline
\end{tabular}

Keterangan: $\mathrm{tn}=$ tidak berbeda nyata pada uji $\mathrm{F} 5 \%, \mathrm{n}=$ berbeda nyata pada uji $\mathrm{F} 5 \%$, sn = berbeda sangat nyata pada uji F $5 \%$. M = Arang sekam, $\mathrm{P}=$ Pupuk organik cair

Tabel 2. Nilai variabel pengamatan pertumbuhan tanaman pakcoy

\begin{tabular}{|c|c|c|c|c|}
\hline \multirow[b]{2}{*}{ Perlakuan } & \multicolumn{4}{|c|}{ Variabel Pengamatan } \\
\hline & $\begin{array}{c}\mathrm{TT} \\
(\mathrm{cm} / \mathrm{tan})\end{array}$ & $\begin{array}{c}\text { PD } \\
(\mathrm{cm} / \tan )\end{array}$ & $\begin{array}{c}\text { JD } \\
\text { (helai/tan) }\end{array}$ & $\begin{array}{c}\text { KD } \\
\text { (unit) }\end{array}$ \\
\hline \multicolumn{5}{|c|}{ Arang Sekam (M) } \\
\hline Tanpa Sekam & $19,68 b$ & $10,87 \mathrm{~b}$ & 14,04 & 34,1 \\
\hline Tanah, Sekam (1:1) & $21,37 \mathrm{ab}$ & $11,95 \mathrm{ab}$ & 14,25 & 33,72 \\
\hline Tanah, Sekam $(2: 1)$ & $21,93 a$ & $12,41 \mathrm{a}$ & 14,12 & 32,81 \\
\hline Tanah, Sekam $(3: 1)$ & $21,22 \mathrm{ab}$ & $11,60 \mathrm{ab}$ & 14,5 & 35,12 \\
\hline F Hitung & $7,73 * *$ & $6,40 * *$ & 1,17 & $3,01 *$ \\
\hline \multicolumn{5}{|c|}{ Pupuk Organik Cair (P) } \\
\hline $0 \mathrm{ml} / \mathrm{l}$ & 20,68 & 11,62 & 13,87 & 33,69 \\
\hline $5 \mathrm{ml} / \mathrm{l}$ & 21,47 & 11,85 & 14,66 & 34,75 \\
\hline $10 \mathrm{ml} / \mathrm{l}$ & 21,10 & 11,54 & 14 & 33,50 \\
\hline $15 \mathrm{ml} / \mathrm{l}$ & 20,95 & 11,83 & 14,37 & 33,80 \\
\hline F Hitung & 0,90 & 0,36 & $3,82 *$ & 1,02 \\
\hline \multicolumn{5}{|c|}{ Interaksi M x P } \\
\hline MOP0 & $18,6 \mathrm{~d}$ & $10,08 \mathrm{c}$ & $13 \mathrm{c}$ & $32,7 \mathrm{ab}$ \\
\hline M0P1 & $19,3 \mathrm{~cd}$ & $10,9 b c$ & $14,5 \mathrm{ab}$ & $35,1 \mathrm{ab}$ \\
\hline M0P2 & $21,2 \mathrm{abc}$ & $11,5 \mathrm{abc}$ & $14,2 \mathrm{abc}$ & $35,0 \mathrm{ab}$ \\
\hline M0P3 & $19,7 \mathrm{bcd}$ & $11 \mathrm{abc}$ & $14,5 \mathrm{ab}$ & $33,6 a b$ \\
\hline M1P0 & $21,3 \mathrm{abc}$ & $12,2 \mathrm{ab}$ & $13,7 \mathrm{abc}$ & $33,8 \mathrm{ab}$ \\
\hline M1P1 & $22,8 \mathrm{a}$ & $12,3 \mathrm{ab}$ & $14,7 \mathrm{ab}$ & $34,1 \mathrm{ab}$ \\
\hline M1P2 & $20,8 \mathrm{abcd}$ & $12,3 a b c$ & $14,7 \mathrm{abc}$ & $32,9 \mathrm{ab}$ \\
\hline M1P3 & $20,7 \mathrm{abcd}$ & $11,7 \mathrm{abc}$ & $14,5 \mathrm{ab}$ & $34,1 \mathrm{ab}$ \\
\hline M2P0 & $21,8 \mathrm{ab}$ & $12,4 \mathrm{ab}$ & $14,3 \mathrm{ab}$ & $31,9 b$ \\
\hline $\mathrm{M} 2 \mathrm{P} 1$ & $22,3 \mathrm{a}$ & $12,8 \mathrm{a}$ & $14,7 \mathrm{ab}$ & $34,2 \mathrm{ab}$ \\
\hline
\end{tabular}




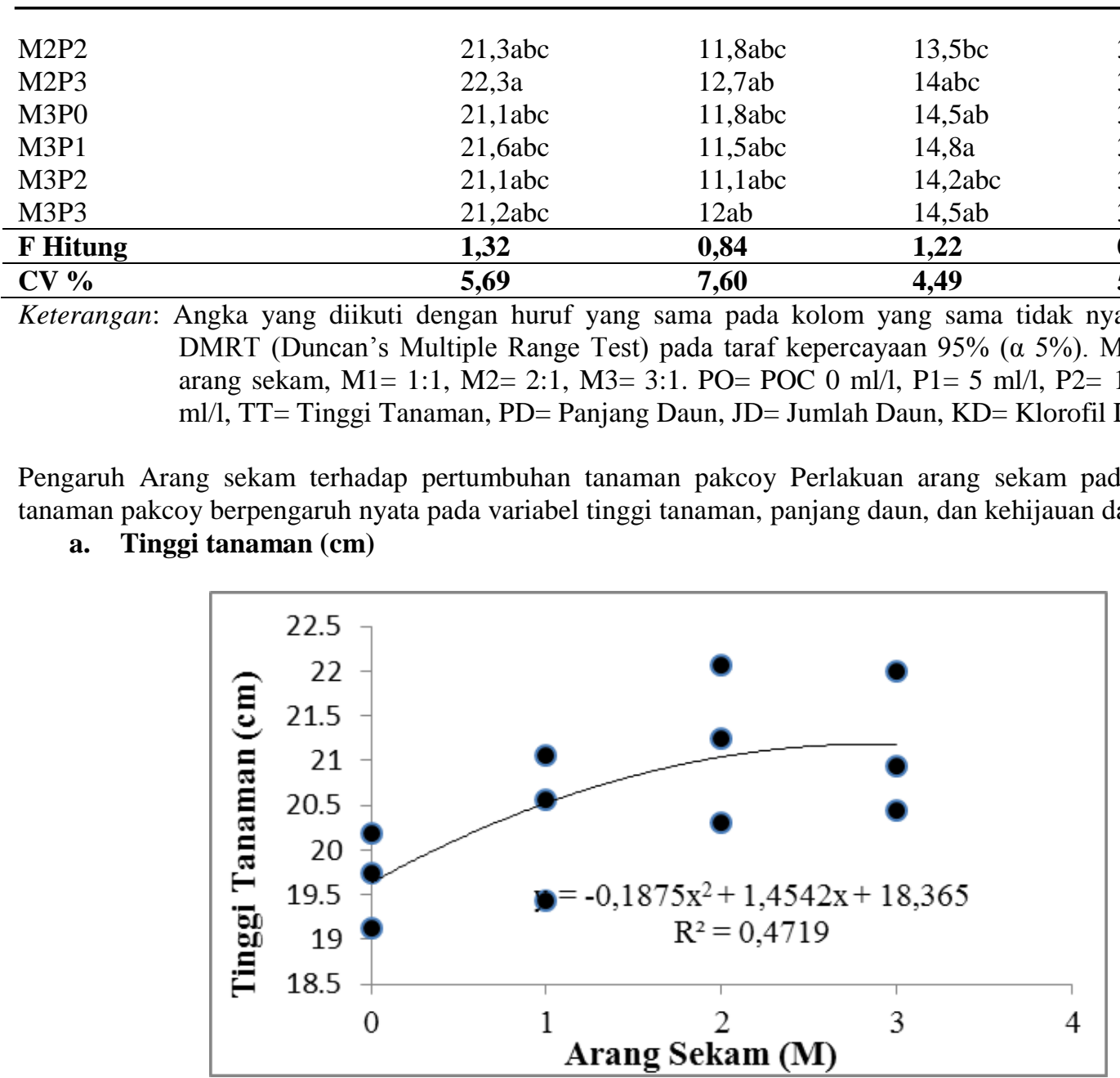

Gambar 1. Grafik pengaruh arang sekam terhadap tinggi tanaman

Hasil rerata menunjukkan bahwa tinggi tanaman tertinggi pada perlakuan tanah arang sekam dengan perbandingan 2:1 (M2), yaitu sebesar $22 \mathrm{~cm}$ dan rerata terendah pada perlakuan kontrol (M0), yaitu sebesar $19,12 \mathrm{~cm}$, serta mampu memberikan pengaruh sebesar 47,19\%. Hasil analisis ragam menunjukkan bahwa perlakuan berbeda perbandingan memberikan respon yang berbeda nyata terhadap tinggi tanaman. Menurut Arlen \& Fauzana (2019), jumlah daun berkaitan dengan tinggi tanaman, dimana semakin tinggi tanaman maka semakin banyak daun yang akan terbentuk, karena daun terbentuk pada nodus-nodus tempat kedudukan daun yang ada pada batang.

b. Panjang daun (cm)

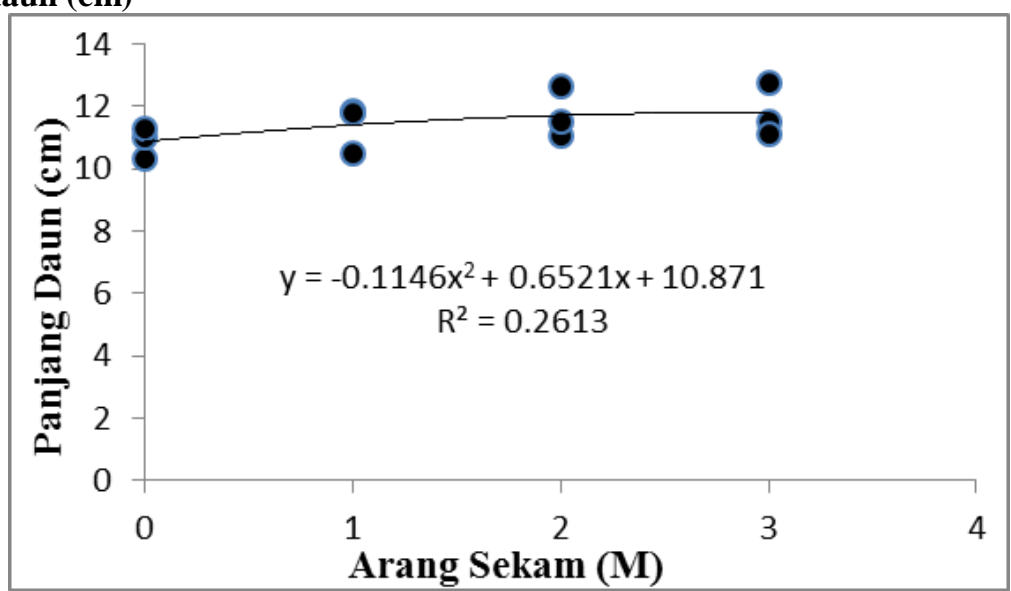

Gambar 2. Grafik pengaruh arang sekam terhadap panjang daun 
Hasil rerata menunjukkan bahwa panjang daun tertinggi pada perlakuan tanah arang sekam dengan perbandingan $3: 1$ (M3), yaitu sebesar 12,75 cm dan rerata terendah pada perlakuan kontrol (M0), yaitu sebesar $10,31 \mathrm{~cm}$ serta mampu memberikan pengaruh sebesar 26,13\%. Hasil analisis ragam menunjukkan bahwa perlakuan berbeda perbandingan memberikan respon yang berbeda nyata terhadap panjang daun. Penambahan arang sekam pada media tumbuh akan menguntungkan karena dapat memperbaiki sifat tanah di antaranya adalah mengefektifkan pemupukan karena selain memperbaiki sifat fisik tanah (porositas, aerasi), arang sekam juga berfungsi sebagai pengikat hara (ketika kelebihan hara) yang dapat digunakan tanaman ketika kekurangan hara, hara dilepas secara perlahan sesuai kebutuhan tanaman/slow release (Komarayati et al., (2003).

c. Kehijauan daun (unit)

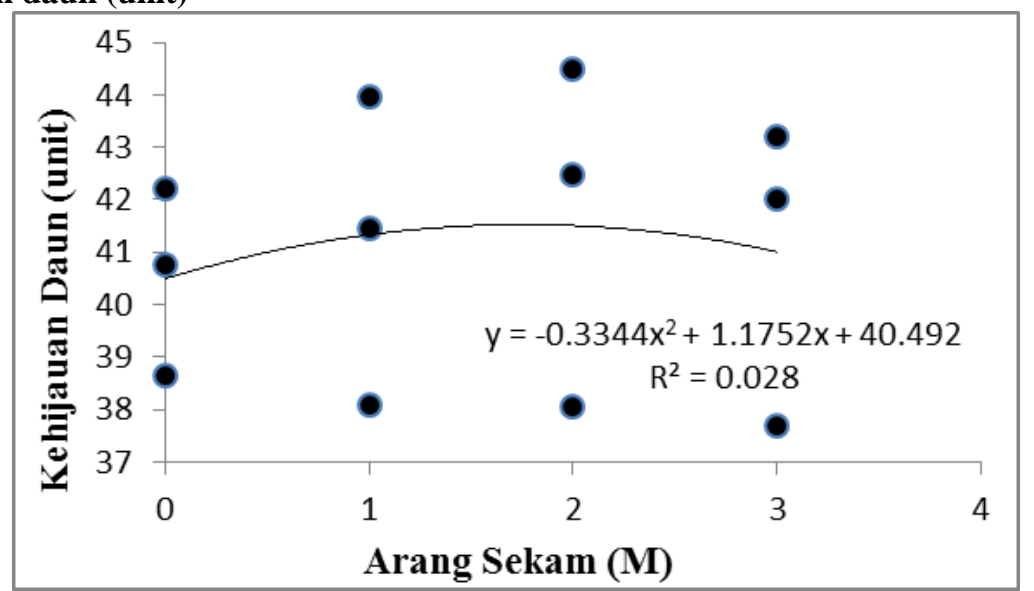

Gambar 3. Grafik pengaruh arang sekam terhadap kehijauan daun,

Hasil rerata menunjukkan bahwa kehijauan daun tertinggi pada perlakuan tanah arang sekam dengan perbandingan $2: 1$ (M2), yaitu sebesar 44,47 unit dan rerata terendah pada perlakuan $3: 1$ (M3), yaitu sebesar 37,67 unit serta mampu memberikan pengaruh sebesar 2,8\%. Hasil analisis ragam menunjukkan bahwa perlakuan berbeda perbandingan memberikan respon yang berbeda nyata terhadap kehijauan daun. Menurut Sulistyaningsih et al., (2005), daun yang lebih hijau diduga memiliki kandungan klorofil yang tinggi. Luas daun dapat digunakan untuk menggambarkan tentang kandungan total klorofil daun tiap individu tanaman. Permukaan daun yang semakin luas diharapkan mengandung klorofil lebih banyak.

Pengaruh pupuk organik cair (SO-Kontan Fert) terhadap pertumbuhan dan hasil tanaman pakcoy

Perlakuan pupuk organik cair berpengaruh nyata terhadap variabel jumlah daun.

a. Jumlah daun (helai)

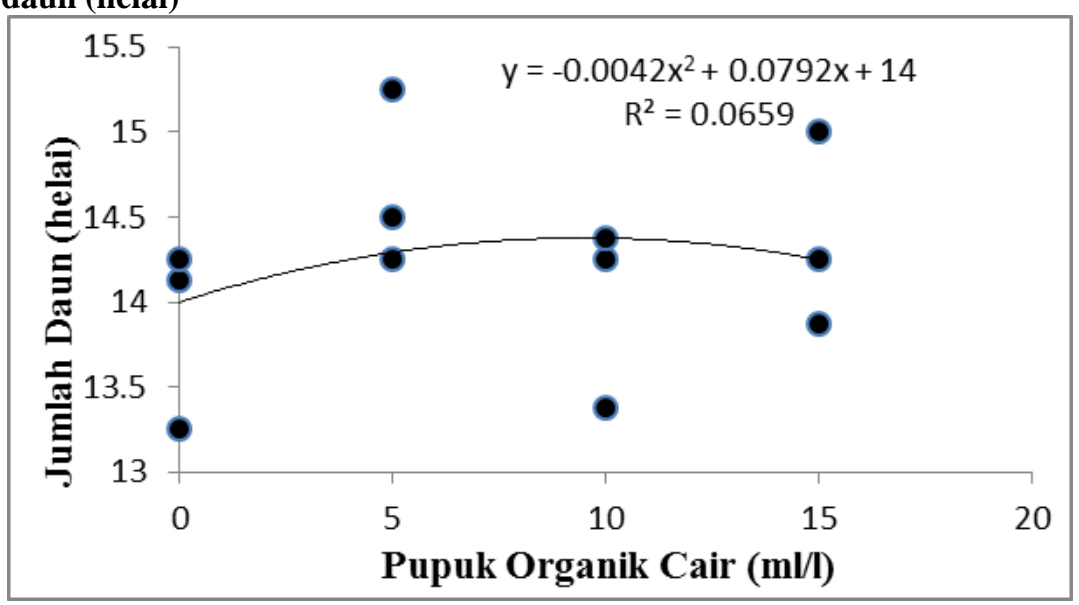

Gambar 4. Grafik pengaruh pupuk organic cair terhadap jumlah daun.

Hasil rerata menunjukkan bahwa jumlah daun tertinggi pada perlakuan pupuk organik cair dengan konsentrasi 5ml/1 (P1), yaitu sebesar 14,67 helai dan rerata terendah pada perlakuan kontrol (P0), yaitu sebesar 12,25 helai serta mampu memberikan pengaruh sebesar 6,59\%. Hasil analisis ragam menunjukkan bahwa perlakuan berbeda volume memberikan respon yang berbeda nyata terhadap jumlah daun. Hal ini sesuai dengan penelitian yang dilakukan Febrianna et al. (2018) bahwa adanya perbedaan jumlah daun tanaman pada 30 HST 
diduga karena adanya pengaruh interval dan dosis pemberian pupuk organik cair serta peningkatan jumlah daun tanaman terjadi dengan bertambahnya umur tanaman.

\section{KESIMPULAN}

1. Pemberian arang sekam pada media tanaman pakcoy pada perbandingan $3: 1$ mampu meningkatkan tinggi tanaman sebesar 47,19 cm, dan panjang daun sebesar 26,13 cm. Perbandingan $2: 1$ mampu meningkatkan kehijauan daun sebesar 2,8 unit.

2. Pemberian pupuk organik cair (SO-Kontan Fert) konsentrasi $5 \mathrm{ml} / \mathrm{l}$ mampu meningkatkan jumlah daun sebesar 6,59 helai.

3. Kombinasi media tanah dan arang sekam dengan pupuk organik cair (SO-Kontan Fert) menunjukkan tidak adanya pengaruh peningkatan terhadap seluruh parameter pengamatan yang diamati.

\section{DAFTAR PUSTAKA}

Arlen, Feby \& Fauzana, Hafiz. 2019. Pengaruh pemberian dosis pupuk kascing dan pupuk NPK terhadap pertumbuhan bibit tanaman kopi arabika (Coffea arabica. L). Jurnal Jom Fapeta, 6 (1) : 1-14.

Badan Pusat Statistik. 2020. Produksi Tanaman Sayuran di Jawa Tengah. : https://jateng.bps.go.id/. Diakses 19 Januari 2021.

Cahyono, B. 2003. Teknik dan Strategi Budidaya Sawi Hijau. Yayasan Pustaka Nusatama, Yogyakarta.

Febrianna, Monica., P. Sugeng., \& K. Novalia. 2018. Pemanfaatan pupuk organik cair untuk meningkatkan serapan nitrogen dan produksi sawi (Brassica juncea L.) pada tanah berpasir. Jurnal Tanah dan Sumberdaya Lahan, 5 (2): 1009-1018.

Gustia, H. 2013. Pengaruh penambahan sekam bakar pada media tanam terhadap pertumbuhan dan produksi tanaman sawi (Brassica juncea L.). Jurnal Widya Kesehatan dan Lingkungan, 1 (1) : 12-17.

Rahmawati, D. Irma., P. K. Indah., \& M. Anton. 2018. Pengaruh konsentrasi pupuk P terhadap tinggi dan panjang akar Tagetes erecta L. (Marigold) terinfeksi mikoriza yang ditanam secara hidroponik Jurnal Sains dan Seni, 7 (2) : 2337-3520.

Rosyida., \& A. S. Nugroho. 2017. Pengaruh dosis pupuk majemuk NPK dan plant growth promoting rhizobacteria (PGPR) terhadap bobot basah dan kadar klorofil daun tanaman pakcoy (Brassica rapa L.). Jurnal Bioma, 6 (2) : 42-56.

Rukmana, R. 1994. Bertanam Sayuran Sawi. Kanisius, Yogyakarta.

Suciati (2018) Pengaruh Media Tanam dengan Pengayaan PGPR dan Trichodermasp. Terhadap Kandungan N, Nilai pH dan EC (Electrical Conductivity), Serta Produksi Tanaman Selada. Skripsi. Universitas Jenderal Soedirman, Purwokerto.

Sulistyaningsih, E, Kurniasih B., \& Kurniasih E. 2005. Pertumbuhan dan hasil caisin pada berbagai warna sungkup plastik. Jurnal Ilmu Pertanian, 12(1): 65-76.

Wijaya, Kelik. 2010. Pengaruh konsentrasi dan frekuensi pemberian pupuk organic cair hasil perombakan anaerob limbah makanan terhadap pertumbuhan tanaman sawi (Brassica juncea L.). Skripsi. Universitas Sebelas Maret, Surakarta. 